\title{
Products from Under-Utilised Plant Seeds as Poultry Feed Ingredients
}

\author{
A. Ologhobo ${ }^{1}$, R. Mosenthin ${ }^{2}$ and O.O Alaka ${ }^{3}$. \\ 'Division of Nutritional Biochemistry and Toxicology, Depertment of Animal Science. \\ 'Institute of Animal Nutrition, Unioersity of Hohenheim, Stuttgart, Germany. \\ Department of Veterinary Pathology, Unioersity of Ibadan, Ihadan, Nigeria.
}

\begin{abstract}
To study some of the potential hazards of plant seeds, an experiment was conducted to study the effect of inclusion of raw jackbean, Canavalia ensiformis, and limabean, Plaseolus lunatus, $(0,250$ and $500 \mathrm{~g} / \mathrm{kg})$ in broiler chicken diets $(0-28$ days), on the performance and the cytopathological changes produced in the internal organs of the chicks. Relative pancreas weight increased significantly $(P<0.05)$ and histological alterations in the lungs showed severe atelectasis, thickening of the alveolar septa and bronchiolar epithelial hyperplasia. Slight henorrhages were observed in the intestinal walls of growing chicks fed $250 \mathrm{~g} / \mathrm{kg}$ and $500 \mathrm{~g} / \mathrm{kg}$ of jackbean and limabean respectively. The livers showed marked congestion of the sinusoids and the centrolobular veins while the kidneys showed distension of the capillary vessels with numerous thrombi. The results indicate structural alterations in the internal organs of chicks fed plant seeds and these could be attributed to the presence of allelochemicals in the seeds and their effects in broiler chickens.
\end{abstract}

\section{Description of Problem}

Continuing disquiet over the use of animal byproducts in livestock nutrition has provided renewed impetus for the greater exploitation of conventional and novel plant seeds both as food and as industrial raw materials. Recent outbreaks of diseases such as BSE in livestock, arguably caused by feeding animal products to animals that do not normally consume them, have cast doubts regarding the suitability of feeding animal-derived proteins to non-carnivorous species. Plants therefore become the preferred sources of protein for these species.

There have been a number of efforts in the past decades to test the suitability of a number of plantderived proteins for pigs, poultry and aquaculture species. Many of these have concentrated on species such as soyabean, cotton seed meal, sunflower seed meal, groundnut meal, sorghum and millet which require environmental and soil conditions and energy subsidies that restrict the scope for increasing their production. In addition, they are in great demand for human consumption and industrial uses. With the prospects of increasing direct human demand for nutrients derived from these sources, they could not be expected to contribute greatly towards satisfying demands from new sources such as the poultry feed industry. The importance of the development of non-human-food grade feed resources whose growth can cope with the projected and fast growth of the sector has been stressed.

There is therefore, a need to examine other plants that can grow on degraded soil and require lower external energy subsidies. Alongside their potential in the production of feed ingredients, these species can help reclamation of degraded areas. Several hardy plant species can assist in 
reclamation of eroded land by increasing the organic matter content of the soil and acting as carbon sinks and dust traps. Alley-cropping with these plants would enable inter-cropping with annuals such as vegetables a few years after initial planting. These multipurpose plants and their products, taking their availability and potential for growth into account, could be considered as protein sources in feeds after adequate treatment. Plants that are capable of resisting adverse soil and climatic conditions often contain a diverse array of anti-nutritional allelochemicals which induce toxic effects ranging from loss of hair and wool to severe pathological disorders and even death in animals. Significant advances have been made in recent years to establish the nature of these compounds and to assess their effects in animal and man. But as yet no precise figures relating to safe levels of various toxic principles exist, although removal or inactivation often results in a better feed consumption.

The purpose of this paper, therefore, was to investigate the utilisation of jackbean (Canavalia ensiformis) and limabean (Phaseolus lunatus), two under-utilised and little-researched plant species capable of growing on degraded lands under stressful environmental conditions and still sustaining a reasonable production of nutrientrich products having potential as poultry feed ingredients. The levels of various anti-nutrients in them as well as their metabolic and cytotoxic effects in broiler chicks fed these seed legumes were also studied.

\section{Materials and Methods}

\section{Samples}

The raw jackbeans and limabeans used in this study were obtained from local farm centres in Nigeria. Before incorporation into experimental diets, the legume seeds were cleaned to remove foreign material, milled and chemically analysed for their proximate composition (4) and allelochemical contents.

\section{Chemical analysis}

Concentrations of trypsin inhibitor and haemagglutinin inhibitors in the legumes were determined using, respectively, a modified kakade method (23) and haemagglutinin assay (22). The protein precipitable tannin (PPT) content was determined by the method of Hagerman and Butles (1988) using bovine serum albumin, fraction V (Sigma chemical, lot 41H0520). Catechin equivalents (CE), which determine simple flavonoids as well as condensed tannins, was determined by the vanillin-HCL procedure of (7) as modified by (18) and (17). The colorimetric technique of (24) as modified by (19) was used to estimate phytic acid contents and oxalate was assayed by the gravimetric method of Apata and (5). All analyses were done in duplicate.

\section{Diet formulation}

Diets of equal energy and protein contents were formulated by incorporating raw jackbean and limabean seed meal at 250 and $500 \mathrm{~g} \mathrm{~kg}^{-1}$ into broiler diets based on yellow maize (Table 3). A maize-soyabean meal diet served as control and the legume diets were formulated by replacing maize and soyabean in the control diet. All diets were supplemented with $3 \mathrm{~g} \mathrm{~kg}^{-1}$ synthetic DLmethionine to ensure that methionine and cystine were not limiting for growth.

\section{Chicks and management}

One-day-old unsexed broiler chicks of the Hubbard strain $(N=200)$ were used in this experiment. They were ranked by weight, wingbanded and randomly divided into one of five groups of 40 chicks each in a completely randomized design. Each group was further subdivided into five replicates of eight birds each, and each replicate was brooded in electrically heated batteries with raised screen floors. Food and water were supplied ad libitum, and uniform light was provided $24 \mathrm{~h}$ daily. Food intake and chick body weights were recorded on days $0,7,14,21$, and 28 of the feeding trial. Food consumption, weight gain, efficiency of food utilization and mortality were used as measures of chick performance.

\section{Measurements}

At the end of 4 weeks, 8 chickens per treatment (2 per replicate) were selected at random and starved for about $18 \mathrm{~h}$ to empty their crops. They were anaesthetized with diethyl ether and killed by decapitation. The internal organs were dissected out and the lengths of the intestinal sections (duodenum, jejunum, ileum and ceca) were 
measured. The weights of livers, kidneys, hearts, spleens, brains, lungs, adrenals and pancreases were recorded. For histological analysis, tissue samples of each organ were taken and immersed in formaldehyde (1\%), fixed in Bouin's solution and embedded in paraffin. Cross sections of each organ were made at a thickness of $5 \mu$ with a microtome (Leitz Wetzlar), stained with haematoxylin-eosin and examined by light microscopy.

\section{Statistical analysis}

The data were analysed according to the General Linear Models procedure for ANOVA (21) and differences among treatment means were determined using the Duncan's multiple range test.

\section{Results}

The proximate compositions of raw milled jackbean and limabean seeds are shown in Table 2. Both legumes showed similarities in their crude protein, ash and metabolisable energy contents while crude fibre and total carbohydrate were different. The concentrations of allelochemicals in the two legumes (Table 3) were quite high but there were considerable differences in trypsin inhibitors, hemagglutinin, phytic acid, canavanine and cyanogenic glycoside contents. The concentration of trypsin inhibitor in limabean was twice the level in jackbean, and while canavanine was present in jackbean alone, cyanogenic glycoside was detected in limabean but not in jackbean. The concentrations of allelochemicals were generally more in limabean than in jackbean seeds.

The performances of the chicks fed on the control and legume diets are shown in Table 4. All jackbean and limabean diets significantly $(\mathrm{P}<0.05)$ reduced weight gain compared with the control. Growth inhibitions were more severe in the diets containing $500 \mathrm{~g} / \mathrm{kg}$ jackbean and limabean. Feed intake followed a similar trend to weight gain except that birds on $250 \mathrm{~g} / \mathrm{kg}$ jackbean diet which consumed slightly more feed than the birds on the control diet $(P>0.05)$. Feed conversion efficiency and efficiency of feed utilization were also significantly $(\mathrm{P}<0.05)$ reduced and were poorest for $500 \mathrm{~g} / \mathrm{kg}$ limabean diet. Chick mortality was significantly $(P<0.05)$ increased by dietary treatments with $500 \mathrm{~g} / \mathrm{kg}$ jack bean and lima bean diets producing 28 and $33 \%$ mortalities respectively.

Weights of organs as a percentage of body weight are shown in Table 5. There were significant $(P<0.05)$ differences in the weights of the liver, pancreas, brain and small intestine among dietary treatments. The liver decreased in size while the kidney, pancreas, brain and small intestine increased but the differences between the control and $250 \mathrm{~g} / \mathrm{kg}$ jack bean diets were not significant $(P>0.05)$ for the pancreas and small intestine.

The results of histopathological changes are summarized in Table 6. Almost all liver samples revealed a diffuse parenchymatous and/or vacuolar degeneration of hepatocytes with a mild to moderate hyperaemia. In the groups fed $500 \mathrm{~g} /$ $\mathrm{kg}$ jackbean and limabean diets, cases of coagulative necrosis and congestion of liver sinusoids were apparent. The prevalent changes in the kidneys of chicks fed $500 \mathrm{~g} \mathrm{~kg}^{-1}$ jackbean and limabean diets were congestion of the glomeruli and slight hyperaemia. Mild cases of proximal tubular epithelial degeneration (necrosis) and medullary congestion were found in chicks fed $250 \mathrm{~g} / \mathrm{kg}$ limabean and $500 \mathrm{~g} / \mathrm{kg}$ jackbean and lima bean diets. In addition to the relative increase in the weights of the pancreas in chickens fed jackbean and limabean diets, there were evidences of pancreatic acinar hypertrophy in all birds apart from those on the control diet.

The structural alterations in the lungs ranged from mild to severe thickening of the alveolar septa, hyperaemia and hyperplasia of bronchiolar lymph nodes. The most distinct cases were observed in birds on $500 \mathrm{~g} / \mathrm{kg}$ jackbean and limabean diets. Histological changes observed in the spleen were depletion of the lymphoid follicles and congestion of the medullary sinusoids; these were more pronounced in chicks fed

$500 \mathrm{~g} / \mathrm{kg}$ limabean diet and mild in those fed $250 \mathrm{~g} / \mathrm{kg}$ jack bean and lima bean diets and 500 $\mathrm{g} / \mathrm{kg}$ limabean diet. The adrenals showed a general congestion of the adrenal medulla and glomerular tufts while the brains were marked with congestion of cells in the cerebrum and cerebellum of chicks fed $500 \mathrm{~g} / \mathrm{kg}$ jackbearhand limabean diets. The most common intestinal, change was nonseparating enterities which was very distinct in 
Table 1. Proximate composition of jackbean and limabean seeds (g/kg DM)

\begin{tabular}{lll}
\hline & Jackbean & Limabean \\
\hline Dry matter & 915.0 & 905.0 \\
Ash & 36.0 & 38.0 \\
Crude Protein $(\mathrm{N} \times 6.25 \mathrm{~g} / \mathrm{kg})$ & 278.5 & 253.6 \\
Crude Fibre & 48.2 & 22.7 \\
Ether extract & 31.0 & 18.5 \\
Total Carbohydrate & 606.3 & 667.2 \\
Estimated metabolisable energy $(\mathrm{MJ} / \mathrm{kg})$ & 11.2 & 10.5 \\
\hline
\end{tabular}

Table 2. Allelochemical contents of jackbean and limabean seeds.

\begin{tabular}{lll}
\hline & Jackbean & Limabean \\
\hline $\begin{array}{l}\text { Trypsin inhibitor activity } \\
\text { (Tiu/mg) }\end{array}$ & 41.6 & \\
Haemagglutinin activity & & 87.2 \\
(Hu/mg protein) & & \\
Protein precipitable tannin $(\mathrm{g} / \mathrm{kg})$ & 73.0 & 54.0 \\
Condensed tannin $(\mathrm{g} / \mathrm{kg})^{3}$ & 3.5 & 5.7 \\
Phytic acid (mg/100g) & 2.0 & 3.4 \\
Canavanine $(\mathrm{mg} / \mathrm{g})$ & 650.0 & 872.0 \\
Cyanogenic $\mathrm{glycoside}$ & 32.6 & - \\
(mg HCN $100 \mathrm{~g})$ & & 4.28 \\
Oxallic acid $(\mathrm{mg} / \mathrm{g})$ & - & 5.87 \\
\hline
\end{tabular}

'Tiu/mg protein $=$ Trypsin inhibitor units per mg protein

${ }^{2} \mathrm{Hu} / \mathrm{mg}$ protein $=$ Haemagglutinin units per mg protein

${ }^{3}$ Measured as Catechin equivalents

chicks on $500 \mathrm{~g} / \mathrm{kg}$ jackbean and limabean diets and mild in those on $250 \mathrm{~g} / \mathrm{kg}$ diets. There was also a mild case of epithelium desquamation in the duodenum of birds fed $500 \mathrm{~g} / \mathrm{kg}$ limabean diet.

\section{Discussion}

The experiment reported here was designed to investigate the effects of raw jackbean and limabean diets on the growth performance and histopathology of a variety of broiler chicken organs. The upper limit of the dietary concentrations of raw beans fed to the birds (500 $\mathrm{g} / \mathrm{kg}$ ) may seem extreme but this was done to magnity the effects of allelochemicals and to reduce interacting influences from maize and soyabean meal. The results obtained confirm the findings of $(20,2)$ and $(15)$, that allelochemicals are toxic natural constituents of legumes, which, when ingested orally or injected into the animal bring about histopathological alterations which usually result in death.

The results obtained with respect to the growth of chicks underscore the poor nutritive value of raw legumes as animal feed and buttress the contention of (12), namely, that the nutritive value of raw legumes is lower than that predicted from their protein content or amino acid composition. Generally, feed intake, weight gain and feed conversion efficiency of the control diet fed birds were significantly better than those of 
birds fed on $250 \mathrm{~g} / \mathrm{kg}$ or $500 \mathrm{~g} / \mathrm{kg}$ jackbean and limabean diets, clearly demonstrating the detrimental effects of these legumes in the unprocessed state. In the absence of methionine deficiency, the presence of allelochemicals (16) and low protein digestibility (11) are the main reasons explaining the growth depression of birds fed raw legumes.

The toxic effects of allelochemicals in the jackbean and limabean diets caused a significant reduction in the relative weights of the liver and an increase in the weights of kidney, pancreas, brain and small intestine. These observations corroborate previous findings $(2,14)$. The fact that limabean diets, in which trysin inhibitor (TI) activity was twice the content in jack bean, resulted in the largest pancreatic size, implicates trypsin inhibitor as the key factor responsible for this physiological anomaly. Cyanide-containing limabean diets induced significantly higher kidney weights. The key enzyme in cyanide detoxification (rhodanase) is located mainly in the kidney and whether the increased activity is contributory to the increased weight of the kidney is speculative.

The considerable disruption of internal structural organs and the associated intracellular changes consequent to feeding raw jackbean and limabean, indicates considerable alterations in the metabolic and secretory functions of these organs. The changes in the pancreatic acinar cells of jackbean and limabean-fed chicks are in keeping with the report of (13), who showed decreased pancreatic enzyme activities in pigs fed on diets containing raw kidney beans. They suggested that such decreases are the consequences of poor protein digestibility and interference with systemic protein utilization, resulting in insufficient amino acids for protein synthesis. Additional evidence in studies with rats kept on bean lectin diet (Aletor, 1987) indicated that, at least in part, the pancreatic lesions are induced or exacerbated by lectininduced changes in intestinal function. Similar alterations in the duodenum and pancreas have been reported in other studies with broilers fed with different levels of faba beans and peas (20, 25).

The degeneration of hepatocytes in the liver, depletion of the lymphoid follicles of spleen, and thickening of the alveolar septae in the lungs observed in $500 \mathrm{~g} / \mathrm{kg}$ jackbean and limabean-fed chicks, were less marked in birds fed $250 \mathrm{~g} / \mathrm{kg}$ jackbean and limabean diets. The absence of severe histopathological lesions in these birds may be attributed to the lower concentrations of allelochemicals in the legume diets fed at the 250 $\mathrm{g} / \mathrm{kg}$ level. (15) have reported on the suitability of aqueous heated limabean at $250 \mathrm{~g} / \mathrm{kg}$ as a dietary ingredient for poultry without any histopathological disorder in the organs of experimental animals. (8) also reported that broilers can tolerate up to $280 \mathrm{~g} / \mathrm{kg}$ of jackbean in their diets provided that canavanine and other antinutritional factors are removed and the bean autoclaved. However, when higher concentrations of legumes were used, some researchers reported adverse effects on chick growth (26). The inclusion of $500 \mathrm{~g} \mathrm{~kg}^{-}$jack bean and lima bean in the present study caused 28 and $33 \%$ mortalities respectively, while most of the surviving chickens were weak, lethargic and anorexic and tended to wander about aimlessly.

The study demonstrated that the nutritional potentials of raw jackbean and limabean as feed ingredients for poultry are limited by the presence of several allelochemicals. To improve the nutritional value of the beans and make them acceptable to poultry, it is important that these allelochemicals are reduced, inactivated or eliminated. Significant advances have been made in the development of processing techniques which have effectively reduced the toxic allelochemicals in legumes to safe levels and enhanced their protein quality. (9) provided experimental evidence for improvement in nutritional value of some legumes, based on alteration of protease inhibitors and lectins by reagents, which disrupt the tertiary structure of the proteins. Extrusion, dry roasting, atmospheric steaming (toasting), pressurized steaming (pressure cooking; autoclaving) have been studied as ways to improve the utilization of beans by industrial and experimental heating processing. However, despite the effectiveness of these processes, residual allelochemicals remain in processed beans, especially the heat-stable toxic factors, which induce toxic effects in the animal after a long period of feed consumption. It is 
Table 3. Composition of experimental diet (g/kg)

\begin{tabular}{llllll}
\hline Ingredients & Control & & Jackbean & & Limabean \\
& $(0)$ & $250(\mathrm{~g} / \mathrm{kg})$ & $500(\mathrm{~g} / \mathrm{kg})$ & $250(\mathrm{~g} / \mathrm{kg})$ & $500(\mathrm{~g} / \mathrm{kg})$ \\
\hline Maize & 526.0 & 534.7 & 332.2 & 541.2 & 331.2 \\
Soyabean meal (44\% protein) 246.0 & - & - & - & - & - \\
Raw Jackbean & - & 250.0 & 500.0 & - & - \\
Raw Limabean & 55.0 & - & - & 250.0 & 500.0 \\
Fish meal & 55.0 & 67.5 & 41.6 & 65.0 & 45.0 \\
Brewer's grain & 65.0 & 65.0 & 42.4 & 60.0 & 40.0 \\
Calcium Carbonate & 7.5 & 7.5 & 65.0 & 65.0 & 65.0 \\
Dicalcium phosphate & 2.5 & 2.5 & 7.5 & 7.5 & 7.5 \\
Salt & 5.0 & 5.0 & 2.5 & 2.5 & 2.5 \\
Vitamin premix & 0.8 & 0.8 & 5.0 & 5.0 & 5.0 \\
Trace elements & 3.0 & 3.0 & 3.0 & 0.8 & 0.8 \\
Methionine & & & & 3.0 & 3.0 \\
& & & & \\
Determined chemical composition $(\mathrm{g} / \mathrm{kg})$ & & & & \\
Dry matter & 943.7 & 931.6 & 927.1 & 946.5 & 935.5 \\
Crude protein & 229.9 & 233.6 & 237.5 & 238.0 & 230.9 \\
Crude fibre & 42.1 & 52.0 & 41.7 & 49.6 & 41.2 \\
Ether extract & 40.1 & 32.5 & 38.8 & 33.7 & 36.5 \\
Ash & 75.6 & 70.8 & 88.1 & 80.4 & 79.6 \\
Total carbohydrate & 612.4 & 611.1 & 593.9 & 598.3 & 611.8 \\
Metabolizable energy $(\mathrm{MJ} / \mathrm{kg})$ & 12.0 & 11.8 & 12.1 & 11.9 & 11.8 \\
\hline
\end{tabular}

Table 4. Effect of raw jackbean and limabean diets on performance of broiler chickens at 28 days of age.

\begin{tabular}{|c|c|c|c|c|c|c|}
\hline \multirow[t]{2}{*}{ Parameters } & \multirow{2}{*}{$\begin{array}{l}\text { Control } \\
\text { Diet }\end{array}$} & \multicolumn{2}{|c|}{ Jackbean } & \multicolumn{2}{|c|}{ Limabean } & \multirow[t]{2}{*}{ SEM } \\
\hline & & 250 & 500 & 250 & 500 & \\
\hline & & $(\mathrm{g} / \mathrm{kg})$ & $(\mathrm{g} / \mathrm{kg})$ & $(\mathrm{g} / \mathrm{kg})$ & $(\mathrm{g} / \mathrm{kg})$ & \\
\hline Weight gain (kg/chick) & $0.85^{\mathrm{a}}$ & $0.52^{\mathrm{b}}$ & $0.30^{\circ}$ & $0.48^{\mathrm{b}}$ & $0.20^{\circ}$ & 022 \\
\hline Feed intake (kg/chick) & $1.04^{\mathrm{a}}$ & $1.08^{\mathrm{a}}$ & $0.83^{\mathrm{b}}$ & $1.03^{\mathrm{a}}$ & $0.71^{\mathrm{b}}$ & 0.27 \\
\hline $\begin{array}{l}\text { Feed conversion efficiency } \\
\text { (kg feed intake/ kg weight gain) } \\
\text { Efficiency of feed utilization }\end{array}$ & $1.22^{\mathrm{d}}$ & $2.05^{\mathrm{c}}$ & $2.76^{\mathrm{b}}$ & $2.15^{\mathrm{c}}$ & $3.55^{a}$ & 0.71 \\
\hline ( $\mathrm{kg}$ weight gain/ kg feed intake) & $0.82^{a}$ & $0.48^{b}$ & $0.36^{\circ}$ & $0.46^{b}$ & $0.28^{c}$ & 0.16 \\
\hline Mortality $(\%)$ & $2^{i}$ & $16^{\mathrm{b}}$ & $28^{\mathrm{n}}$ & $20^{a t b}$ & $33^{a}$ & 5.51 \\
\hline
\end{tabular}

abc Mean within a column with different superscripts are significantly different $(p<0.05)$

$\mathrm{SEM}=$ Standard error of mean 
Table 5. Organ weights as influenced by dietary raw legumes (\% body weight)

\begin{tabular}{|c|c|c|c|c|c|c|}
\hline \multirow[t]{2}{*}{ Organs } & \multirow{2}{*}{$\begin{array}{l}\text { Control } \\
\text { Diet }\end{array}$} & \multicolumn{2}{|c|}{ Jackbean } & \multicolumn{2}{|c|}{ Limabean } & \multirow[t]{2}{*}{ SEM } \\
\hline & & $\begin{array}{l}250 \\
(\mathrm{~g} / \mathrm{kg})\end{array}$ & $\begin{array}{l}500 \\
(\mathrm{~g} / \mathrm{kg})\end{array}$ & $\begin{array}{l}250 \\
(\mathrm{~g} / \mathrm{kg})\end{array}$ & $\begin{array}{l}500 \\
(\mathrm{~g} / \mathrm{kg})\end{array}$ & \\
\hline Liver & $4.20^{\mathrm{a}}$ & $3.36^{\circ}$ & $2.89^{\mathrm{b}}$ & $3.45^{\mathrm{b}}$ & $3.00^{\mathrm{b}}$ & 0.72 \\
\hline Kidney & $1.00^{\circ}$ & $1.95^{b}$ & $2.32^{\mathrm{ab}}$ & $2.06^{b}$ & $2.65^{\mathrm{a}}$ & 0.64 \\
\hline Pancreas & $0.23^{\circ}$ & $0.33^{\mathrm{b}}$ & $0.45^{a}$ & $0.40^{\mathrm{a}}$ & $0.48^{:}$ & 0.13 \\
\hline Heart & 0.38 & 0.40 & 0.47 & 0.39 & 0.44 & 0.10 \\
\hline Spleen & 0.12 & 0.11 & 0.09 & 0.07 & 0.06 & 0.04 \\
\hline Brain & $0.98^{\mathrm{c}}$ & $2.00^{\mathrm{ab}}$ & $2.65^{\mathrm{a}}$ & $1.06^{\mathrm{c}}$ & $1.77^{\mathrm{ab}}$ & 0.35 \\
\hline Lungs & 0.69 & 0.68 & 0.70 & 0.70 & 0.72 & 0.08 \\
\hline Adrenal & 0.04 & 0.04 & 0.04 & 0.05 & 0.06 & 0.01 \\
\hline Small intestine & $2.30^{\mathrm{b}}$ & $3.00^{\mathrm{ab}}$ & $3.77^{\mathrm{a}}$ & $3.40^{\mathrm{a}}$ & $3.95^{\mathrm{a}}$ & 0.43 \\
\hline Colorectum & 0.46 & 0.50 & 0.70 & 0.65 & 0.85 & 0.30 \\
\hline Combined caeca & 1.60 & 1.70 & 2.25 & 1.95 & 2.27 & 0.44 \\
\hline
\end{tabular}

Mean differently superscripted are significantly different from one another $(p<0.05)$

$\mathrm{SEM}=$ Standard error of the Mean difference

important therefore, that attention is paid to the inclusion rate of feedstuffs of plant origin in poultry feeds in order to avoid possible cumulative effects of residual toxic substances. In addition, careful control of processing variables is essential to prevent functional as well as nutritional damage to proteins resulting from excess application of heat. Improved utilization of plant proteins can be maximized through an understanding of their physical and chemical components, and implementation of diverse processing strategies. This will also facilitate development of feed products of high nutritional quality that can be effectively used by poultry and other farm animals for food.

\section{Acknowledgement}

This project was partly supported by the Alexander von Humboldt Foundation, Bonn, Germany, through the award of a fellowship which was spent at the Institute of Animal Nutrition, Hohenheim University, Stuttgart, Germany. The authors gratefully acknowledge the secretarial and technical assistance of Mr Chidi Anagu of the Institute of Plant Breeding, Hohenheim University, Stuttgart, Germany, in the preparation of this manuscript. 
Table 6. Histopathological lesions of organs in chicks fed with raw jackbean and limabean diets.

\section{Organs}

Liver:

$$
\begin{aligned}
& \text { Congestion of sinusoids } \\
& \text { Coagulative necrosis } \\
& \text { Degeneration of hepatocytes }
\end{aligned}
$$

Kidney:

\begin{tabular}{llllll} 
& Control & \multicolumn{2}{c}{ Jackbean } & \multicolumn{3}{c}{ Limabean } \\
\cline { 2 - 5 } Diet $^{l}$ & 250 & 500 & 250 & 500 \\
& $(\mathrm{~g} / \mathrm{kg})$ & $(\mathrm{g} / \mathrm{kg})$ & $(\mathrm{g} / \mathrm{kg})$ & $(\mathrm{g} / \mathrm{kg})$ \\
\hline & - & ++ & ++ & ++ & ++ \\
& - & ++ & ++ & ++ & ++ \\
& - & $1 / 2$ & ++ & $1 / 2$ & ++
\end{tabular}
Congestion of glomeruli
Distension of capillary
vessels with numerous
thrombi
Hyperimia

Pancreas: Acinar hypertrophy

Spleen: $\quad$ Congestion of medullary sinusoids

Depletion of lymphoid

follicles

Atrophy

Lungs: $\quad$ Congestion of alveolar walls

Oedema

Thickening of alveolar septa

Adrenals: Congestion of adrenal

medulla and glomerular tufts

Heart: Congestion

Brain: Congestion of cerebrum and cerebellum cells

Gizzard Hyaline degeneration

Intestine: Epithelium desquamation Enteritis 
Products fron under-utilised plant seeds as Poultry Feed

\section{References}

1. Aletor V.A. (1987). Nutritional studies in the rat fed a lima bean lectin extract. Journal .Anim. Physiol. Anim. Nutr.57: 32-41.

2. Aletor V.A. and Fetuga B.L. (1985). Effect of dietary sub-lethal levels of lima bean lectin on relative organ weights, pancreatic and intestinal lectin (EC 3.4.21.4) and chymotrypsin (EC 3.4.21.1) in the rat. Die Nalinung 33: 355-360.

3. Aletor V.A. and Res C.C. (1993). Allelochemicals in plant food and feedstuffs: Nutritional, Biochemical and Physiopathological Aspects in Animal Production. Veterinary and Human Toxicology, 35: 57-67.

4. AOAC (1984) Official Methods of Analysis, $14^{\text {th }}$ edn (Washington, AOAC).

5. Apata D.F. and Ologhobo A. D. (1995). Some aspects of the biochemistry and nutritional Value of African yambean seed (Sphenostylis sternocarpa). Food Chemistry 3 : 271-280.

6. Apata D.F. and Ologhobo A.D. (1997). Trypsin inhibitor and other antinutritional factors in tropical legume seeds. Tropical Science 37: $52-$ 59.

7. Burns R.E. (1971). Methods for estimating tamnin content in grain sorghum. Agon ). 63 511-572.

8. D' Mello J.P.F. and Walker A. G. (1994). Detoxification of jackbean (Canavalia ensifonnis): Studies with young chicks. Animal Feed Sci. and Tech. 33: 117-127.

9. Friedman, M. and Gumbmann, M.R. (1986). Nutritional improvement of legume proteins through disulfide interchange. In: $M$. Friedman (Editor), Nutritional and Toxicological Significance of Enzyme Inhibitors in Foods. Plenum Press, New York, NY, pp.357-389.

10. Hagerman A.E. and Butler L..G. (1978). Protein precipitation method for the quantitative determination of tannins. J. Agric. Food Chem. 26(4): 809-812.
11. Hauschild A. and Kohler R. (1991). Influence of dietary fibre on digestibility and organic matter of different pea genotypes in growing pigs. $6^{\text {th }}$ International Symposium on Protein Metabolism and Nutrition. Herning, Denmark, 9-14 June, 1991.

12. Liener I. E. and Hasdai A. (1986). The effect of the long-term feeding of raw soy flour on the pancreas of the mouse and hamster. Advances in Experimental Medicine and Biology 199: 189-198.

13. Meyer R.O., Froseth J. A and Coon C.N. (1992). Protein utilization and toxic effects of raw beans (Phaseolus vulgaris) for young pigs. J. of Anim.Sci. 55: 1087-1098.

14. Ologhobo A. D. (1992). Nutritive value of some tropical (West African) legumes for poultry. J. Applied Animal Res. 2: 93-104.

15. Ologhobo A. D., Apata D. F. and Oyejide A. (1994). Utilisation of raw jack bean and jack bean fractions in diets for broiler chicks. British Poultry Science 34: 323-337.

16. Ologhobo A.D., Idowu J. I. and Sadiq A. A. (1998). Tannins and phytic acid in cooked legumes on apparent protein digestibility in the intestinal tract of broiler chicks. In : Recent Advances of Research on Antinutritional Factors in Legume Seeds and Rapeseeds. A. I. M. Jansman and J. Huisman (Editors). A. B. wageningen, The Netherlands.

17. Price M.L., Scoyov S.V. and Butler, L.G. (1978). A critical evaluation of the vanillin reaction as an assay for tannin in sorghum grain. $J$. Agric. Food Chem. 26(5): 1214-1219.

18. Price M.L. and Butler L.G. (1977). Rapid visual estimate and spectophotometric determination of tannin content of sorghum. J. Agric. Food Chem. 25(6): 1268-1273.

19. Reddy N.R., Balakrishnan C.V. and Salunkhe D.K. (1978). Phytase phosphorus and mineral changes during germination and cooking of blackgram seeds. Joumal of Food Sci. 43: 540545.

20. Rubio L.A., Brenes A. and Castano M. (1990). Histological alteration to the pancreas and intestinal tract produced by raw faba bean ${ }^{x}$. diets in growing chicks. Brit. Poult. Sci. 30: 15-28. 
21. Statistical Analysis System Institute Inc. (1989). SAS Introductory Guide. SAS Institute Inc., Cary, NC.

22. Valdebouze P., Bergezon, E., Gaborit T. And Delort-Laval J. (1980). Content and distribution of trypsin inhibitors and haemagglutinins in some legume seeds. Canadian Journal of Plant Science 60: 695-701.

23. Van Oort M.G., Hamer R.J. and Slager E.A. (1989). The trypsin inhibitor assay: Improvement of an existing method. Proceeding of a Workshop on Antinutritional Factors in Legume Seeds. pp.80-86 (Pudoc. Wageningen, The Netherlands.
24. Wheeler E.I and Ferrel R.E. (1971). A method for phytic acid determination in wheat and wheat fractions. Cereal Chem. 48: 312-316.

25. Yuste E.L. (1993). Histological alterations to the pancreas and intestinal tract produced by raw peas (Pisum sativum) diet in growing chicks. Proceedings of the Second International Worlshop on Antinutritional Factors in Legume Seeds. A.F.B. van der Poel, J. Huisman and H.s. Saini (Eds). Wageningen Press, 211-215.

26. Zorita, E., Sanz-Arias, R. and Tovar, M. (1990). Anales de la faacultd de Veterinaaria de leon. Nutr. Abstr. 16: 14-20. 